\title{
Exploration and Research on Innovation and Entrepreneurship Education of Physical Education Major in Colleges and Universities
}

\author{
Cao Jia \\ School of Physical Education, Baicheng Normal University, Baicheng, 137000, China \\ wushucaojia@163.com
}

Keywords: Colleges and Universities, Physical Education Major, Innovation and Entrepreneurship Education

\begin{abstract}
In order to promote physical education students to adapt to the society better and promote the all-round development of physical education students, colleges and universities can carry out innovation and entrepreneurship education for students majoring in physical education. Innovation and entrepreneurship education, can truly achieve the education of "proselytizes, instructs, dispels doubt". This paper discusses and studies the innovation and entrepreneurship education of PE major in colleges and universities, hoping to promote the good development of PE majors in colleges and universities through the analysis of this paper.
\end{abstract}

\section{Introduction}

Carrying out innovative entrepreneurship education in colleges and universities, not only can improve the employment rate of colleges and universities, but also enable college students to achieve better self-worth. However, in the traditional Chinese concept, sports students have a higher risk of starting a business, which makes many people hesitate to start a business. In addition, educational ideas and teaching methods, also affect the smooth implementation of innovative entrepreneurship education. Therefore, it is necessary to discuss and research the innovation and entrepreneurship education of PE major in the corresponding colleges and universities, which will be discussed in detail below.

\section{Challenges Faced by Innovation and Entrepreneurship Education of Physical Education Major in Colleges and Universities}

Innovation and entrepreneurship education of physical education major in colleges and universities faces a great challenge, the following specific analysis is carried out.

\subsection{Challenges in Conceptual Awareness.}

At the present stage, the innovation and entrepreneurship education of PE major in colleges and universities in China has not given full play to its value. The reason is that many colleges and universities have backward ideas and do not have a correct understanding of innovation and entrepreneurship education, which seriously affects the value of innovation and entrepreneurship education. There is also the fact that colleges and universities do not attach importance to the construction of relevant systems of innovative entrepreneurship education. Innovation and entrepreneurship education is not only the theoretical guidance for college students to innovate and start their own business, but also needs to cultivate the relevant practical ability of physical education students in colleges and universities, so that the risk of entrepreneurship can be reduced to the minimum, that can also promote the overall development of physical education students in colleges and universities. If we do not pay attention to the construction of the related system of innovative entrepreneurship education, it will disconnect the theoretical education and practical education of education itself, and seriously affect the value of innovative entrepreneurship education [1]. In addition, some students of physical education major in colleges and universities have a one-sided understanding of entrepreneurship. Some students of physical education in 
colleges and universities believe that entrepreneurship is a long-term and complex task, and require a lot of capital investment; some students of physical education in colleges and universities believe that entrepreneurship is a great risk, so, some people think that entrepreneurship needs a lot of customer resources and brand awareness. It can not be said that these cognitive errors, and can only be said to be too one-sided, entrepreneurship itself also needs services, management capabilities, innovative entrepreneurial expertise and other soft power.

\subsection{Challenges in Terms of Teacher Capacity.}

As we all know, excellent teachers can improve the quality of teaching. It is necessary for teachers to have professional knowledge and practical ability to carry out innovative and entrepreneurial education for students majoring in physical education in colleges and universities, which puts forward high requirements for teachers themselves. But at present, our country lacks this kind of education talented person seriously. In view of this, some colleges and universities only carry out the relevant policies, and do not give technical guidance to the students majoring in physical education in colleges and universities, which will lead to the innovation and entrepreneurship education of physical education major in colleges and universities only staying at the level of theoretical knowledge education, seriously affect the improvement of teaching quality. Moreover, in order to save teachers resources, some colleges and universities have their counselors or class leaders organize innovative and entrepreneurial activities. In this case, physical education students in colleges and universities not only do not master the relevant professional knowledge, but also can not understand the value of innovative education, that not only violates the original intention of the education department to set up innovative entrepreneurship education curriculum, but also causes the waste of teaching resources to a certain extent, and affects the overall development of physical education students in colleges and universities [2].

\subsection{Challenges in Teaching Methods.}

Under the background of examination-oriented education, the teaching mode of our country is relatively simple, and the education of colleges and universities is no exception. The drawback of this teaching mode lies in its limitation, and this teaching mode has geographical limitations, and itself is only suitable for classroom education or related activities in school. At the same time, the teacher as the main body also restricts the exertion of student autonomy in colleges and universities. All these will affect the smooth progress of innovation and entrepreneurship education of physical education major in colleges and universities, and will also lead to the lack of relevant entrepreneurial practice ability among college students, especially those majoring in physical education.

\section{Necessity of Innovation and Entrepreneurship Education for Physical Education Majors in Colleges and Universities}

The innovation and entrepreneurship education of PE majors in colleges and universities is mainly to cultivate the innovative ability and entrepreneurial ability of $\mathrm{PE}$ majors, which is conducive to promoting PE students to better adapt to the future development of society, and also can promote the sports major students better development. In recent years, the sports cause of our country develops vigorously. Flying man Liu Xiang won the Athens Olympic Games on Aug. 28, 2004, becoming the first man Olympic champion in Chinese track and field events. Yao Ming, the 2002 NBA first draft pick, became the first basketball player in China, who was the first foreign champion in the history of NBA. Li Na, the first Asian to win a Grand Slam singles title, made a historic breakthrough in Chinese tennis. These people, promotes the development of Chinese sports cause, and let our country sports cause ushered in new opportunity. It is necessary for relevant educators to carry out innovation and entrepreneurship education for PE majors in colleges and universities, which can not only promote the diversified development of sports in our country, but also train more and more excellent sports talents for our country. Therefore, the education department should realize the necessity of innovation and entrepreneurship education for physical 
education students in colleges and universities, conform to the trend of the development of the times, and constantly improve the system of innovation and entrepreneurship education for physical education majors in colleges and universities [3].

\section{The Main Contents of Innovation and Entrepreneurship Education for PE Majors in Colleges and Universities}

\subsection{Good Psychological Quality of Entrepreneurship.}

It is very important to have a good psychological quality of entrepreneurship. Entrepreneurship itself has a lot of uncontrollable factors, which means that entrepreneurs themselves will face very unpredictable difficulties and challenges. Therefore, it is necessary to carry out innovative psychological quality education for the students majoring in physical education in colleges and universities, so that they have the courage not to be afraid of difficulties. Only students of physical education in colleges and universities have good psychological quality and excellent professional knowledge can they succeed in starting a business. In addition, the good psychological quality of entrepreneurship can make students of physical education in colleges and universities adapt to the constantly developing society. At this stage, the pace of development of the times is getting faster and faster. Entrepreneurs who want to better adapt to society should take their time to cope with outside disadvantages and improve themselves. If the entrepreneur, meet a little difficulty give up, then will only let start a business half way, let own effort be lost. Therefore, one of the main contents of innovative entrepreneurship education for PE majors in colleges and universities is to train them to have good psychological quality of entrepreneurship [4].

\subsection{Positive Sense of Entrepreneurship.}

A positive entrepreneurial consciousness is based on one personal own ideals, three views and beliefs to formulate the orientation, nature and needs of entrepreneurship. Positive entrepreneurial awareness include positive entrepreneurial enthusiasm and strong entrepreneurial communication awareness. First of all, entrepreneurs should have a positive entrepreneurial enthusiasm. It is also a preliminary stage of development for students majoring in physical education in our country. Therefore, the success rate of students majoring in physical education in colleges and universities is not high, and a large part of the reason is that physical education students in institutions of higher learning do not have a positive sense of entrepreneurship [5]. Only when we have a positive sense of entrepreneurship, can we attend various lectures on entrepreneurship, learn and improve our own professional knowledge, lay a solid foundation for entrepreneurship, and improve the success rate of entrepreneurship. Secondly, the innovative entrepreneurship education of physical education in colleges and universities should train students to establish a strong sense of communication. Entrepreneurship itself is complex and difficult, so many colleges and universities students choose the form of team entrepreneurship. In that case, it is necessary to strengthen the communication consciousness of PE majors in colleges and universities. Therefore, the educators should set up a positive sense of entrepreneurship in the innovation and entrepreneurship education of physical education major in colleges and universities.

\subsection{Integrated Entrepreneurial Capacity.}

The level of comprehensive entrepreneurial ability directly determines the success of entrepreneurship. Entrepreneurial ability, is specifically divided into hardware and software capabilities. The hardware ability includes the investment of human and material resources, and the software ability is the professional knowledge and the basic quality of starting a business. In the innovation and entrepreneurship education of physical education major in colleges and universities, it is necessary to let the students of physical education major in colleges and universities have a better comprehensive ability to set up a business, that is, to let the students of physical education major in institutions of higher learning plan the resources of starting a business, so that they can have a clear idea. There is also through education to improve the quality of students majoring in 
physical education. From food safety to industrial pollution, the country has many policies, but these problems still exist. On July 15, 2018, the State Drug Administration issued a notice saying that during the flight inspection of Changchun Evergreen Biotechnology Company, it was found that the company had recorded fake production of rabies vaccine for people. People Daily commented that rabies vaccine was fake, terrible. In modern society, there is also a terrible phenomenon, that is, fruit farmers do not eat their own fruit and vegetable farmers do not eat their own vegetables, because there are a large number of pesticides and other substances harmful to human health. What manifests here, is not only our country concerned legal loophole, or the related enterprise personnel lacks the basic quality [6]. Therefore, in the innovative entrepreneurship education of physical education major in colleges and universities, students should have good entrepreneurial quality, so as to promote the economic development of our country and ensure the safety of people life and property.

\section{Concrete Measures of Innovation and Entrepreneurship Education for PE Specialty in Colleges and Universities}

\subsection{Strengthening the Ideological Understanding of Innovation and Entrepreneurship Education of Physical Education in Colleges and Universities.}

Strengthening the ideological understanding of innovation and entrepreneurship education in physical education in colleges and universities is conducive to promoting teachers and students in colleges and universities to understand innovation and entrepreneurship education and to promote the perfection of innovation and entrepreneurship education system. For example, schools can regularly organize activities to enable college PE students to have a deeper understanding of the relevant entrepreneurial knowledge. Of course, teachers also play an important role in the activities and should give evaluation to the performance of physical education students in their activities, praise and encourage students with strong awareness of entrepreneurship, which is conducive to promoting the students of colleges and universities to improve their self and promote the improvement of their professional knowledge.

\subsection{Establishing Teaching Methods with Characteristics of Physical Education Major.}

The quality of teaching method directly affects the teaching efficiency. Therefore, the teaching methods with the characteristics of physical education should be formulated in the innovation and entrepreneurship education of physical education major in colleges and universities, which in this way can attract the enthusiasm of students majoring in physical education in colleges and universities, and improve the teaching efficiency of innovation and entrepreneurship. Teachers should pay attention to the formulation of teaching methods, which can not only meet the learning needs of students majoring in physical education in colleges and universities, but also ensure that the teaching has certain practicality. Only in this way can students of physical education major in colleges and universities give full play to their autonomy according to their own interests, and the innovative entrepreneurship teaching itself has certain pertinence, and the teaching method can be adapted to the study and development of students majoring in physical education in colleges and universities.

\subsection{Creating a Good Environment for the Innovation and Entrepreneurship Education of Physical Education Majors in Colleges and Universities.}

To create a good environment for the implementation of innovation and entrepreneurship education for physical education students in colleges and universities is to provide a good practical platform for students majoring in physical education in colleges and universities. Colleges and universities can carry out academic seminars on entrepreneurial knowledge or organize students majoring in physical education in colleges and universities to carry out relevant entrepreneurial situational experiences. In this way, students majoring in physical education in colleges and universities can realize their own shortcomings, understand the reasons for the failure of the project, 
and accumulate valuable experience for the students majoring in physical education in colleges and universities in the future, and can also cultivate the practical ability of physical education students in colleges and universities, which can effectively improve the success rate of entrepreneurship [7]. In addition, colleges and universities can also offer training courses to provide practical opportunities for physical education students in colleges and universities so as to improve their professional skills and practical abilities.

\subsection{Organizing Students Majoring in Physical Education in Colleges and Universities to Make Clear Career Planning.}

To organize the students of physical education major to make a clear career plan is to let them combine their own interests and abilities to make a career plan. Career planning itself can play a key role in guiding college students majoring in physical education. For example, some sports majors in colleges and universities enjoy writing and can plan their own careers, such as writers, poets or lyricists. Some students of physical education in colleges and universities like to travel and become adventurers. Fitness coaches or tour guides can also be used; some college sports students like swimming and can become swimmers, coaches or divers. In a word, you need to plan your career before you start a business, so you can love your career and ensure your success.

\section{Conclusion}

Implementation of innovation and entrepreneurship education can make the students of physical education major in colleges and universities have good psychological quality and positive sense of entrepreneurship, which can effectively improve the success rate of entrepreneurship. From this, we can see the necessity of innovation and entrepreneurship education for PE majors in colleges and universities. In order to carry out the innovation and entrepreneurship education of physical education students in colleges and universities, it is necessary to strengthen the ideological understanding of the innovation and entrepreneurship education of sports majors, and to formulate teaching methods with the characteristics of physical education, and to create a good environment for college physical education students to carry out innovative and entrepreneurial education, and to organize students of physical education major to make a clear career plan. We hope through the analysis of this article to finally promote the good development of physical education major students in colleges and universities.

\section{References}

[1] LIU Zhenzhong, ZHANG Chaoan, ZHAO Zhigang. Construction of innovation and entrepreneurship education practice system in physical education institutes [J]. Journal of Shandong Sport University, 2016(11).

[2] WU Zhejun. Innovation and entrepreneurship education in colleges and universities and its enlightenment [J]. Journal of Nanchang Institute of Technology, 2017(05)

[3] WU Weiwei, JIN Jinru, WANG Wei. Exploration and practice of innovative entrepreneurship education for college students [J]. Journal of Zhejiang Sci-Tech University (Social Sciences Edition), 2016(04).

[4] WANG Yangming. Entrepreneurship education: a strategic choice to improve the employment competitiveness of college students [J]. Education Exploration, 2016(03).

[5] LI Hanyi. Analysis on the path of employment and entrepreneurship of college students majoring in physical education [J].Talent Resources Development, 2016(20).

[6] TAN Qian. Discussion about the cultivation of innovative talents in physical education specialty [J].Technology \& Management, 2017(04).

[7] ZHAO Lefa. Construction of entrepreneurial education model for college students majoring in physical education[J].Journal of Qiqihar Junior Teachers' College, 2015(03). 